\title{
PENGARUH SUBSTITUSI MINYAK IKAN DENGAN MINYAK KEDELEI DALAM LEMAK PAKAN TERHADAP PERTUMBUHAN BENIH KERAPU LUMPUR, Epinephelus coioides
}

\author{
Ketut Suwirya, Muhammad Marzuqi, Agus Prijono, dan Nyoman Adiasmara Giri
}

\begin{abstract}
ABSTRAK
Lemak adalah komponen pakan yang dapat berfungsi sebagai sumber energi dan asam lemak esensial. Kebutuhan lemak dan jenis asam lemak esensial pada ikan berbeda menurut jenis ikan. Percobaan ini dilaksanakan untuk mengevaluasi pengaruh substitusi minyak ikan dengan minyak kedelei dalam lemak pakan terhadap pertumbuhan kerapu lumpur, Epinephelus coioides. Ikan untuk percobaan berukuran $9,13 \pm 0,71 \mathrm{~g}$ dan dipelihara dalam bak volume 100 liter dengan sistem air mengalir selama 10 minggu. Kepadatan ikan dalam tiap bak adalah 12 ekor. Suhu dan salinitas air pemeliharaan adalah $28^{\circ} \mathrm{C}-30^{\circ} \mathrm{C}$ dan $31-33 \mathrm{ppt}$. Pakan percobaan dibuat dalam bentuk pelet kering dengan penambahan kadar lemak yang sama yaitu $9 \%$. Kadar minyak ikan pada masing-masing pakan disubstitusi dengan minyak kedelei sebesar $0 \%(\mathrm{~A})$; $3 \%(B) ; 4,5 \%$ (C); $6 \%$ (D); dan $9 \%$ (E). Hasil percobaan menunjukkan bahwa substitusi minyak ikan dengan minyak kedelei sebagai lemak pakan mempengaruhi pertumbuhan benih kerapu lumpur $(P<0,05)$. Substitusi minyak ikan dengan minyak kedelei $>3 \%$ dalam pakan (pakan $C, D$, dan E) menyebabkan pertumbuhan benih kerapu lumpur cenderung menurun. Pertumbuhan spesifik benih kerapu lumpur yang diberi pakan $A, B, C, D$, dan $E$ masing-masing 0,$0253 ; 0,0259$; 0,$0231 ; 0,0228$; dan 0,0228 .
\end{abstract}

\section{ABSTRACT: Substitution effect of dietary fish oil by soybean oil on growth of estuary grouper (Epinephelus coioides) juveniles. By: Ketut Suwirya, Muhammad Marzuqi, Agus Prijono, and Nyoman Adiasmara Giri}

Lipid is dietary component for energy and essential fatty acid resources. Requirement of lipid source for fish varies depend on fish species. The present study was conducted to evaluate the substitution effect of dietary fish oil by soybean oil on growth of estuary grouper juveniles Epinephelus coioides. Twelve fish of $9.13 \pm 0.71 \mathrm{~g}$ in body weight were reared in each 100 litter's tank for 10 weeks with flow through system. Temperature and salinity of rearing waters were $28^{\circ} \mathrm{C}-30^{\circ} \mathrm{C}$ and $31-33$ ppt. respectively. The lipid content of dry pellet experiment diets was supplemented $9.0 \%$. Dietary fish oil in experiment diets were substituted by soybean oil so that the soybean oil in experiment diets became $0 \%(A), 3 \%(B), 4.5 \%(C), 6 \%(D)$, and $9 \%(E)$. The result of experiment showed that substitution dietary fish oil by soybean oil affected growth of estuary grouper juveniles $(P<0.05$ ). Dietary fish oil substitution by soybean oil $>3 \%$ (diets $C, D$, and $E$ ) reduced growth of estuary grouper juvenile. Specific growth rate of estuary grouper juveniles fed diets $A, B, C, D$, and $E$ were $0.0253,0.0259,0.0231,0.228$, and 0.0228 respectively.

KEYWORDS: estuary grouper juvenile, fish oil, soybean oil, growth

\section{PENDAHULUAN}

Lemak adalah komponen pakan yang merupakan sumber energi dan asam lemak esensial untuk menunjang pertumbuhan ikan. Kadar lemak dalam pakan berpengaruh terhadap pertumbuhan ikan red sea bream (Vergara et al., 1996) dan red drum (Williems \& Robinson, 1988). Ikan kerapu, $E$. areolatus yang diberikan pakan dengan kandungan lemak $10 \%$ serta protein $60 \%$ menghasilkan pertumbuhan yang terbaik (Chu et al., 1996).
Sumber lemak yang digunakan dalam pakan sangat mempengaruhi pertumbuhan karena memiliki komposisi asam lemak yang berbeda. Minyak ikan banyak mengandung asam lemak dari kelompok n-3 HUFA dan minyak kedelei mengandung asam lemak dari keluarga lenoleat $(n-6)$. Kedua kelompok asam lemak tersebut merupakan asam esensial bagi beberapa jenis ikan.

Beberapa hasil penelitian menunjukkan bahwa kebutuhan asam lemak esensial secara kualitatif maupun kuantitatif sangat bergantung pada jenis ikan 
(Higashi et al., 1964; Arai et al., 1971; Castell et al., 1972). Secara umum, ikan laut lebih membutuhkan keluarga asam lemak linolenat ( $n-3$ ) dibandingkan keluarga asam lemak linoleat $(n-6)$ (Cowey \& Sargent, 1977; Kanazawa et al., 1977). Watanabe et al. (1975) melaporkan bahwa ikan mas (Cyprinus carpio) membutuhkan asam lemak linoleat (18:2n-6) dan asam lemak linolenat (18:3n-3). Ikan kerapu lumpur dapat dibudidayakan di laut dan perairan air payau. Oleh karena itu, kedua kelompok asam lemak tersebut diduga dibutuhkan oleh kerapu lumpur.

Sampai saat ini kebutuhan asam lemak esensial pada kerapu lumpur belum diketahui pada setiap stadia dari siklus hidupnya. Komposisi lemak yang diformulasi untuk pakan kerapu lumpur didasarkan pada hasil percobaan dari jenis kerapu lainnya yaitu menggunakan sumber lemak yang berasal dari organisme laut dan harganya relatif lebih mahal.

Percobaan ini dilaksanakan untuk mengevaluasi pengaruh substitusi minyak ikan dengan minyak kedelei sebagai sumber lemak dalam pakan terhadap pertumbuhan benih kerapu lumpur.

\section{BAHAN DAN METODE}

Sumber protein pakan percobaan seperti tepung ikan dan cumi diekstraksi dengan metode Bligh \&
Dryer (1959) untuk mengurangi kandungan lemaknya. Pakan yang digunakan dalam percobaan ini adalah pakan kering dengan kadar air $5,8 \%-6,5 \%$. Pakan percobaan disusun dengan kandungan energi yang sama. Adapun komposisi pakan percobaan disajikan pada Tabel 1. Total lemak yang ditambahkan dalam fomulasi pakan adalah $9 \%$ dengan substitusi minyak ikan oleh minyak kedelei pada masing-masing pakan adalah $0 \%(A) ; 3 \%(B) ; 4,5 \%(C) ; 6 \%(D) ;$ dan $9 \%(E)$ sebagai perlakuan.

Percobaan ini menggunakan benih kerapu lumpur dengan bobot awal $9,13 \pm 0,71 \mathrm{~g}$ dan dipelihara dalam bak-bak polietilin volume $100 \mathrm{~L}$ pada kepadatan 12 ekor/bak dengan sistem air mengalir. Aliran air laut diatur pada debit $200 \mathrm{~mL}$ per menit. Suhu dan salinitas air media pemeliharaan diamati selama percobaan dan kondisinya adalah $28^{\circ} \mathrm{C}-30^{\circ} \mathrm{C}$ dan $31-33 \mathrm{ppt}$. Pemberian pakan 2 kali per hari dan setiap pemberian pakan diamati secara seksama sampai semua ikan tidak mau makan lagi. Jumlah pakan yang diberikan per hari dihitung dengan melihat selisih bobot pakan sebelum dan sesudah pemberian pakan.

Percobaan ini berlangsung selama 10 minggu dan setiap minggu dilakukan pengukuran bobot tubuh untuk melihat perkembangannya. Percobaan ini

Tabel 1. Komposisi pakan percobaan (\%) untuk benih kerapu lumpur

Table 1. Compostion of test diets (\%) for estuary grouper

\begin{tabular}{lccccc}
\hline \multirow{2}{*}{ Bahan (Ingrediens) } & \multicolumn{5}{c}{ No. pakan (Diet no.) } \\
\cline { 2 - 6 } & A & B & C & D & E \\
\hline Kasein (Casein) & 10.0 & 10.0 & 10.0 & 10.0 & 10.0 \\
Tepung ikan (Fish meal) & 50.0 & 50.0 & 50.0 & 50.0 & 50.0 \\
Tepung cumi (Squid meal) & 11.0 & 11.0 & 11.0 & 11.0 & 11.0 \\
Mineral mix ${ }^{1}$ & 2.5 & 2.5 & 2.5 & 2.5 & 2.5 \\
Vitamin mix ${ }^{2}$ & 1.31 & 1.31 & 1.31 & 1.31 & 1.31 \\
Carophylpink & 0.19 & 0.19 & 0.19 & 0.19 & 0.19 \\
CMC & 2.5 & 2.5 & 2.5 & 2.5 & 2.5 \\
Dekstrin (Dextrin) & 13.5 & 13.5 & 13.5 & 13.5 & 13.5 \\
Minyak ikan (Fish oil) & 9.0 & 6.0 & 4.5 & 3.0 & 0.0 \\
Minyak kedelei (Soybean oil) & 0.0 & 3.0 & 4.5 & 6.0 & 9.0 \\
Analisis (Analysis) & & & & & \\
Kadar air (Moisture) & 8.51 & 8.34 & 8.49 & 8.92 & 8.45 \\
Protein kasar (Crude protein) & 49.44 & 48.95 & 49.51 & 49.11 & 49.21 \\
Lemak kasar (Crude lipid) & 10.27 & 10.57 & 10.73 & 10.64 & 10.94 \\
Serat kasar (Fibre) & 10.24 & 9.64 & 9.32 & 9.22 & 10.38 \\
Abu (Ash) & 10.66 & 10.67 & 10.36 & 10.34 & 10.59 \\
\hline
\end{tabular}
$\mathrm{MnSO}_{4} 6.3, \mathrm{CuSO}_{4} 2, \mathrm{CoSO}_{4} .7 \mathrm{H}_{2} \mathrm{O} 0.05, \mathrm{KJ} 0.15$, Dextrine 450, Cellulose 553,51 
dilaksanakan dengan rancangan acak lengkap dengan 5 perlakuan dan 3 ulangan. Data pertumbuhan, konsumsi pakan, dan efisiensi pakan dianalisis menggunakan sidik ragam dan beda antar perlakuan diuji dengan BNT pada taraf nyata $95 \%$. Pada akhir percobaan diambil seekor benih dari masing-masing bak dan dikelompokkan menurut perlakuan untuk analisa asam lemak dari lemak tubuh. Komposisi asam lemak pakan dan ikan percobaan dianalisis dengan gas kromatografi.

\section{HASIL DAN BAHASAN}

Komposisi asam lemak pakan percobaan disajikan dalam Tabel 2. Berdasarkan Tabel 2 terlihat bahwa penurunan kadar minyak ikan dalam pakan, maka akan menurunkan kadar n-3 HUFA dan meningkatkan kadar keluarga asam lemak linoleat (18:2n-6). Dalam hal ini minyak ikan merupakan sumber n-3 dan minyak kedelei sebagai sumber $n-6$.

Hasil percobaan menunjukkan bahwa benih kerapu lumpur yang diberi pakan dengan sumber lemak dari minyak ikan (pakan A) memberikan pertumbuhan spesifik yang ternyata lebih baik $(P<0,05)$ dibandingkan dengan yang diberi pakan dengan sumber lemak dari minyak kedelei (pakan E) (Tabel
3). Benih kerapu lumpur yang diberi pakan dengan sumber lemak adalah minyak ikan 9\% (Pakan A) dan substitusi minyak ikan dengan minyak kedelei sampai 3\% (pakan B) memperlihatkan laju pertumbuhan spesifik yang tidak berbeda nyata $(P>0,05)$, namun substitusi minyak ikan dengan minyak kedelei sampai lebih dari 3\% maka laju pertumbuhan spesifik ikan cenderung menurun (pakan $C, D$, dan E).

Dari hasil analisis asam lemak pakan percobaan (Tabel 2) terlihat bahwa substitusi minyak ikan sebesar 3\% dalam lemak maka kandungan n-3 HUFA dalam lemak menurun dari 17,87\% (Pakan A) menjadi $11,84 \%$ (Pakan B), sedangkan asam lemak keluarga linoleat ( $n-6)$ meningkat dari 2,86\% (Pakan A) menjadi $14,18 \%$ (Pakan B). Berdasarkan Tabel 3 menunjukkan bahwa kadar n-3 HUFA $<11,84 \%$ dalam lemak pakan maka laju pertumbuhan spesifik akan cenderung menurun dan nampaknya n-3 HUFA tidak dapat disubstitusi dengan keluarga asam lemak linoleat ( $n$ $6)$.

Yu \& Shinhuber (1976) melaporkan bahwa penambahan $1 \%$ asam lemak linoleat $(18: 2 n-6)$ dalam pakan tampak menstimulasi pertumbuhan ikan rainbow trout, tetapi pertumbuhannya menurun apabila kadar asam lemak linoleat dalam pakan ditingkatkan

Tabel 2. Komposisi asam lemak pakan percobaan (\%) pada benih kerapu lumpur

Table2. Fatty acid composition of experimental diets (\%) for estuary grouper

\begin{tabular}{|c|c|c|c|c|c|}
\hline \multirow{2}{*}{ Asam lemak (Fatty acids) } & \multicolumn{5}{|c|}{ Pakan percobaan (Experimental diets) } \\
\hline & A & B & $C$ & D & $E$ \\
\hline Miristik (Myristic acid) $(14: 0)$ & 4.68 & 3.36 & 2.61 & 2.05 & 0.75 \\
\hline Pentadekanoat (Pentadecanoic acid) $(15: 0)$ & 0.21 & 0.15 & 0.12 & 0.06 & 0.04 \\
\hline Palmitat (Palmitic acid $(16: 0)$ & 23.64 & 22.99 & 19.21 & 18.31 & 15.72 \\
\hline Palmitoleat (Palmitoleic acid) $(16: 1 n-9)$ & 26.51 & 20.75 & 14.86 & 10.51 & 3.22 \\
\hline Stearat (Stearic acid) $(18: 0)$ & 6.77 & 6.14 & 5.61 & 5.51 & 4.89 \\
\hline Oleat (Oleic acid) $(18: 1 n-9)$ & 13.38 & 14.37 & 13.87 & 15.27 & 18.37 \\
\hline Linoleat (Linoleic acid) $(18: 2 n-6)$ & 0.53 & 12.93 & 26.12 & 33.24 & 47.72 \\
\hline Linolenat (Linolenic acid) $(18: 3 n-3)$ & 2.13 & 5.16 & 5.91 & 5.73 & 6.44 \\
\hline Eikosadienoat (Eicosadienoic acid) $(20: 2 n-9)$ & 0.55 & 0.64 & 0.69 & 0.72 & 0.83 \\
\hline Arasidonat (Arachidonic acid) $(20: 4 n-6)$ & 2.33 & 1.25 & 0.85 & 0.51 & t \\
\hline EPA $(20: 5 n-3)$ & 6.72 & 4.41 & 3.40 & 2.41 & $t$ \\
\hline $\mathrm{DHA}(22: 6 n-3)$ & 11.15 & 7.43 & 5.63 & 3.71 & t \\
\hline $\mathrm{NN}^{*}$ & 1.40 & 0.42 & 1.12 & 1.97 & 2.02 \\
\hline Total & 100 & 100 & 100 & 100 & 100 \\
\hline Total $n-6=18: 2 n-6+20: 4 n-6$ & 2.86 & 14.18 & 26.97 & 33.65 & 47.72 \\
\hline Total $n-3=18: 3 n-3+20: 5 n-3+22: 6 n-3$ & 20.00 & 17.00 & 14.94 & 11.85 & 6.44 \\
\hline n-3 HUFA & 17.87 & 11.84 & 9.03 & 6.12 & $t$ \\
\hline
\end{tabular}

$\mathrm{NN}^{*}=$ tidak dapat diidentifikasi (unidentified)

$\mathrm{T}=$ tidak terdeteksi (undetected) 
menjadi $2,5 \%$ atau $5 \%$. Mereka juga mencatat bahwa kadar asam lemak linoleat lebih tinggi dari $1 \%$ atau kadar keluarga asam lemak n-3 yang sangat tinggi akan menurunkan pertumbuhan coho salmon (Yu \& Sinhuber, 1979). Dalam percobaan ini memperlihatkan bahwa kerapu lumpur yang diberi pakan dengan kandungan n-3 HUFA 1,25\% dan asam lemak linolenat (n-6) $1,50 \%$ masih memberikan pertumbuhan yang baik. Namun pertumbuhannya menurun dengan kadar $n-6>1,50 \%$ dan $n-3$ HUFA $<1,25 \%$.

Asam lemak tak jenuh seperti n-3 HUFA sangat berperan dalam menjaga fermiable membran sel ikan sehingga masuknya nutrien ke dalam sel dan pembuangan sisa metabolisme pada suhu air di bawah suhu $30^{\circ} \mathrm{C}$ tidak terganggu. Kebanyakan ikan air laut mempunyai kemampuan yang terbatas untuk mensintesis n-3 HUFA dari asam lemak n-3 rantai karbon yang lebih pendek (Owen et al., 1975; Kanazawa et al., 1979; Ostrowski \& Divakaran, 1990). Asam lemak n-3 HUFA seperti 20:5n-3 (EPA) dan 22:6n-3 (DHA) merupakan asam lemak esensial bagi kebanyakan ikan laut (Yano \& Fujii, 1975; Fujita et al., 1980; Watanabe et al., 1983; Izquierdo et al., 1989; Webster \& Lovell, 1990). Kekurangan n-3 HUFA mengakibatkan pertumbuhan larva yang lambat, serta tidak sempurnanya pembentukan dan fungsi gelembung renang pada larva ikan (Sorgeloos et al., 1988; Webster \& Lovell, 1990; Koven et al., 1990).

Kebutuhan n-3 HUFA ikan adalah bergantung pada jenis ikan. Kebutuhan n-3HUFA yuwana ikan red drum adalah 0,5\%-1,0\% (Lochmann \& Gatlin, 1993), ikan Korean rockfish dengan bobot $5,9 \mathrm{~g}$ adalah sekitar 0,9\% (Lee et al., 1993), 1,4\% untuk yuwana kerapu bebek (Suwirya et al., 2001) dan 1,5\% untuk benih ikan kerapu macan (Suwirya et al., 2003). Nilai ini mendekati dengan nilai kebutuhan n-3 HUFA untuk ikan kerapu lumpur yang diteliti.

Takeuchi \& Watanabe (1979) melaporkan bahwa kelebihan kadar asam lemak esensial dalam pakan akan menyebabkan pengaruh jelek pada ikan rainbow trout. Penelitian ini menunjukkan bahwa pada penambahan asam lemak linolenat $(18: 3 n-3)$ atau n3 HUFA campuran dari EPA (20:5n-3) dan DHA (22:6n3) dengan perbandingan 1:1 pada pakan dengan kadar empat kali lebih dari yang dibutuhkan ikan menghasilkan pertumbuhan dan efisiensi yang rendah. Selanjutnya dijelaskan bahwa penggunaan lemak dalam pakan haruslah hati-hati dengan memperhatikan jenis dan kandungan asam lemak esensialnya karena kebutuhan asam lemak ikan dapat berubah bergantung pada kadar lemak pakan dan jenis asam lemak dari lemak yang akan digunakan (Watanabe, 1982).

Hasil percobaan (Tabel 3) menunjukkan bahwa benih kerapu lumpur yang diberi pakan dengan sumber lemak dari minyak ikan (pakan A) mempunyai efisiensi pakan lebih tinggi dibandingkan dengan benih yang diberi pakan dengan sumber lemak dari minyak kedelei (pakan $E)(P<0,05)$. Substitusi minyak ikan dengan minyak kedelei sampai $3 \%$ (pakan B) pada benih kerapu lumpur tidak mempengaruhi efisiensi pakan. Namun substitusi minyak ikan dalam pakan benih kerapu lumpur dengan minyak kedelei $>3 \%$ diperoleh kecenderungan efisiensi pakan yang menurun. Hal ini menunjukkan peran n-3 HUFA pada benih ikan kerapu lumpur, sehingga metabolisme menjadi lebih baik.

Hasil yang sama ditunjukkan pada ikan kerapu bebek (Cromileptes altivelis) bahwa benih ikan kerapu bebek yang diberi pakan dengan sumber lemak minyak cumi mempunyai efisiensi pakan yang lebih tinggi dibandingkan dengan pakan dengan sumber lemak minyak kedelei. Substitusi minyak cumi dengan minyak kedelei sebesar $2 \%$ dalam pakan tidak mempengaruhi efisiensi pakan pada kerapu bebek (Suwirya et al., 1999). Hal tersebut berarti bahwa dalam memformulasi pakan benih kerapu lumpur harus memperhatikan sumber lemak yang akan digunakan.

Tabel 3. Pertumbuhan, efisiensi penggunaan, dan konsumsi pakan yuwana kerapu lumpur Table 3. Growth, feed efficiency ratio, and feed intake of juvenile estuary grouper

\begin{tabular}{cccc}
\hline $\begin{array}{c}\text { No. pakan } \\
\text { Diets no. }\end{array}$ & $\begin{array}{c}\text { Pertumbuhan spesifik } \\
\text { Specific growth rate }\end{array}$ & $\begin{array}{c}\text { Efisiensi pakan } \\
\text { Feed efficiency (\%) }\end{array}$ & $\begin{array}{c}\text { Konsumsi pakan } \\
\text { Feed intake (g/ind.) }\end{array}$ \\
\hline A & $0.0253 \pm 0.00201^{\mathrm{a}}$ & $85.24^{\mathrm{a}}$ & $13.11^{\mathrm{a}}$ \\
$\mathrm{B}$ & $0.0259 \pm 0.00133^{\mathrm{a}}$ & $80.24^{\mathrm{a}}$ & $12.91^{\mathrm{a}}$ \\
C & $0.0231 \pm 0.00018^{\mathrm{b}}$ & $79.51^{\mathrm{ab}}$ & $12.62^{\mathrm{a}}$ \\
D & $0.0228 \pm 0.0007^{\mathrm{b}}$ & $78.84^{\mathrm{ab}}$ & $12.51^{\mathrm{a}}$ \\
E & $0.0228 \pm 0.00055^{\mathrm{b}}$ & $72.69^{\mathrm{bc}}$ & $11.92^{\mathrm{a}}$ \\
\hline
\end{tabular}

Nilai tengah dengan huruf yang sama pada kolom tidak berbeda secara statistik $(P<0,05)$ Mean with same superscript in columns are not statistically different $(P<0.05)$ 
Sumber lemak sebaiknya mengandung n-3 HUFA seperti minyak ikan dan minyak yang berasal dari organisme laut lainnya.

Konsumsi pakan per individu selama percobaan tidak dipengaruhi oleh substitusi minyak ikan dengan minyak kedelei dalam pakan (Tabel 3). Hal ini menunjukkan bahwa benih kerapu lumpur dapat menerima pakan yang digunakan dalam percobaan ini.

Hasil percobaan Tucker et al. (1997) diperoleh bahwa ikan red drum dapat memanfaatkan minyak kedelei dan ikan manhaden dalam pakan masingmasing sebesar $1,5 \%$ dan $12,7 \%$. Hal ini menunjukkan bahwa kerapu lumpur dapat memanfaatkan minyak kedelei 3\% dalam pakan atau lebih tinggi dari ikan red drum. Nampaknya kemampuan ikan memanfaatkan lemak pakan sangat erat kaitannya dengan kualitas lemak yang ditentukan oleh komposisi asam lemaknya dan kebutuhan asam lemak esensial dari ikan.

Kandungan n-3 HUFA dalam lemak pakan juga mempengaruhi kadar n-3 HUFA dalam lemak tubuh ikan kerapu lumpur. Makin tinggi substitusi minyak ikan dengan minyak kedelei dalam pakan maka kandungan n-3 HUFA dalam lemak pakan akan menurun (Tabel 2). Penurunan kadar n-3 HUFA dalam pakan menyebabkan penurunan kadar n-3 HUFA dalam lemak tubuh benih kerapu lumpur yang diberikan (Tabel 4). Namun peningkatan kadar asam lemak linoleat $(18: 2 n-6)$ dalam lemak pakan tidak menyebabkan peningkatan kadar asam lemak tersebut dalam lemak tubuh benih kerapu lumpur. $\mathrm{Hal}$ ini kemungkinan bahwa asam lemak linoleat (18:2n6) pakan banyak digunakan sebagai sumber energi dalam metabolisme.
Dari Tabel 4 terlihat bahwa kerapu lumpur yang diberi pakan dengan lemak yang mengandung $n-3$ HUFA sebesar $17,87 \% ; 11,84 \% ; 9,03 \% ; 6,12 \%$; dan $0,0 \%$ selama 10 minggu, kandungan n-3 HUFA lemak tubuhnya berturut-turut $14,62 \% ; 6,48 \% ; 3,54 \% ; 2,16 \%$; dan $1,64 \%$. Hal tersebut jelas tampak bahwa kandungan n-3 HUFA dalam tubuh ikan sebagai refleksi dari asam lemak n-3 HUFA pakan yang diberikan pada benih kerapu lumpur. Pola yang hampir sama tampaknya terjadi pada larva ikan ekor kuning, Seriola quinqueradiata bahwa larva yang diberi pakan dengan kandungan n-3 HUFA lebih tinggi akan menyebabkan kandungan n-3 HUFA lemak tubuhnya akan lebih tinggi (Furuita et al., 1996).

\section{KESIMPULAN}

Sumber lemak pakan benih kerapu lumpur lebih baik berasal dari minyak ikan dibandingkan dengan minyak kedelei. Pada penambahan lemak pakan sebanyak $9,0 \%$; substitusi minyak ikan dengan minyak kedelei pada pakan benih ikan kerapu lumpur dapat dilakukan sebanyak $3 \%$.

\section{DAFTAR PUSTAKA}

Arai, S., T. Nose, and Y. Hashimoto. 1971. A purified test diet for the eel, Anguila javonica. Bull. Freshwater Fish. Res. Lab. Tokyo, 22(12): 161-178.

Bligh, E.G. and W.J. Dryer. 1959. A rapid method of total lipid extraction and purification. Canadian J. Biochem. Physiol., 37: 911-917.

Castell, R.O. Sinnhuber, J.W. Wales, and D.J. Lee. 1972. Essential fatty acids in the diet of rainbow trout (Salmon gardner) growth, feed conversion, and some deficiency gross symptoms. J. Nutr., 102: 77-86.

Chu, J.C.W., K.M.Y. Leung, and R.S.S. Wu. 1996. Nutritional study on the areolated grouper

Tabel 4. Komposisi asam lemak benih kerapu lumpur diberi pakan percobaan (\%)

Table 4. Fatty acid composition of estuary grouper juvenile fed experimental diets (\%)

\begin{tabular}{lrrrrrr}
\hline \multicolumn{1}{c}{$\begin{array}{c}\text { Asam lemak } \\
\text { Fatty acids }\end{array}$} & $\begin{array}{c}\text { Awal } \\
\text { Initial }\end{array}$ & A & B & C & D & E \\
\hline Asam miristik (Myristic acid) (14:0) & 6.92 & 4.16 & 4.35 & 4.59 & 3.94 & 1.28 \\
Asam palmitat (Palmitic acid) (16:0) & 8.43 & 5.53 & 6.03 & 5.15 & 0.57 & 1.35 \\
Asam palmitoleatm(Palmitoleic acid) (16:1n-9) & 28.31 & 19.30 & 25.02 & 24.90 & 24.22 & 10.39 \\
Asam stearat (Stearic acid) (18:0) & 7.88 & 4.88 & 4.56 & 7.03 & 7.31 & 4.23 \\
Asam oleat (Oleic acid) (18:1n-9) & 39.94 & 46.51 & 48.90 & 50.45 & 57.43 & 78.25 \\
Asam linoleatm (Linoleic acid) (18:2n-6) & 5.37 & 3.36 & 4.16 & 4.02 & 3.98 & 2.09 \\
Asam linolenat (Linolenic acid) (18:3n-3) & 0.42 & 1.63 & 0.50 & 0.33 & 0.39 & 0.76 \\
EPA (20:5n-3) & 2.51 & 6.59 & 2.00 & 2.37 & 2.01 & 0.83 \\
DHA (22:6n-3) & 0.21 & 8.04 & 4.48 & 1.17 & 0.15 & 0.81 \\
Total & 100.00 & 100.00 & 100.00 & 100.00 & 100.00 & 100.00 \\
n-3HUFA & 2.72 & 14.62 & 6.48 & 3.54 & 2.16 & 1.64 \\
Asam linoleat (Linoleic acid) (n-6) & 5.37 & 3.36 & 4.16 & 4.02 & 3.98 & 2.09 \\
\hline
\end{tabular}


(Epinephelus areolatus) culture in open sea cages. Proc. The Pecan Conference on Sustainable Aquaculture, 11-14 June 1995. Honolulu, 79 pp.

Cowey, C.B. and J.R. Sargent. 1977. Lipid nutrition in fish. Comp. Biochemist. Physiol., 578: 269-273.

Fujita, S., T. Watanabe, and C. Kitajima. 1980. Nutrition quality of Artemia from different location as living feed from viewpoint of essential fatty acids for marine fish. In G. Personne, P. Sorgelos, O. Roels, and E. Jespers (Eds.). The Brine Shrimp Artemia, Universa Press, Belgium, III: 277-290.

Furuita, H., T. Takeuchi, T. Watanabe, H. Fujimoto, S. Sekiya, and K. Imaizumi. 1996. Requirement of larval yellowtail for eicosapentaenoic acid, docosahexaenoic, and n-3 highly unsaturated fatty acid. Fisheries Science, 62(3): 372-379.

Higashi, H., T. Kaneko, M. Ushiyama, and T. Sugihasi. 1964. Effect of dietary lipids on fish under cultivation II: Effect of ethyl linoleat, ethyl linolenate and ethyl ester of polyunsaturated on deficiency of essential fatty acid in rainbow trout. Vitamine. Kyoto, 30: 271-275.

Izquierdo, M.S., T. Watanabe, T. Takeuchi, T. Arakawa, and C. Kitajima. 1989. Requirement of Larvae Red Sea Bream, Pagrus major for Essential Fatty Acids. Nippon Suisan Gakkaishi, 55: 859-867.

Kanazawa, A., S. Tokiwa, and M. Kayama. 1977. Essential fatty acids in the diet of prawn I: effect of linoleic and linolenic acid on growth. Bull. Japan Soc. Sci. Fish, 43(9): 1,111-1,114.

Kanazawa, A., S. Teshima, and K. Ono. 1979. Conversion of linoleic to $n-3$ highly unsaturated fatty acid in marine fishes and rainbow trout. Bull. Jpn. Soc. Sci. Fish., 46: 1,231-1,233.

Koven, M.W., A. Tandler, G.W. Kissil, D. Sklan, O. Frieslander, and M. Harel. 1990. The effect of dietary $n-3$ polyunsaturated fatty acid on growth, survival, and swim bledder development in Sparus aurata larvae. Aquaculture, 91: 131-141.

Lee, S.M., J.Y. Lee, Y.J. Khang, H.D. Yoon, and S.B. Hur. 1993. n-3 HUFA requirement of Korean rockfish, Sebastes schlegeli. Bull. Korean Fish. Soc., 26(5): 477-492

Lochmann, R.T. and D.M. Gatlin. 1993. Essential fatty acids requirement of juvenile red drum (Sciaenops ocellatus). Fish Physiol. Biochem., 12: 221-2,351.

Owen, J.M., J.W. Adron, C. Middleton, and C.B. Cowey. 1975. Elongation and desaturation of dietary fatty acid in Turbot (Scopthalamun maximus) and rainbow trout. Lipid, 10: 258-271.

Ostrowski, A.C. and S. Divakaran. 1990. Survival and bioconversion of $\mathrm{n}-3$ fatty acid during early develpment of dolpin (Corypaena hyppuras) larvae fed oil-enriched rotifer. Aquaculture, 89: 273-285.

Sorgeloss, P., P. Leger, and P. Laveus. 1988. Improved larval rearing of European, Asian seabass, seabream, mahi-mahi, siganid, and milkfish using enriched diets for rotifer and Artemia. Word Aquacult., 19: $78-79$.
Suwirya, K., M. Marzuqi, dan N.A. Giri. 1999. Pengaruh proporsi minyak cumi dan kedelei dalam pakan terhadap pertumbuhan dan efisiensi pakan yuwana kerapu tikus, Cromileptes altivelis. Dalam A. Sudrajat, E.S. Heruwati, J. Widodo, dan A. Poernomo (Eds.) Prosiding Seminar Nasional Penelitian dan Desiminasi Teknologi Budi Daya Laut dan Pantai, Jakarta, 2 Desember 1999, p. 272-276.

Suwirya, K., N.A. Giri, dan M. Marzuqi 2001. Pengaruh n3 HUFA terhadap pertumbuhan dan efisiensi pakan yuwana ikan kerapu bebek, Cromileptes altivelis. In Sudradjat, A., E.S. Heruwati, A. Poernomo, A. Rukyani, J. Widodo, dan E. Danakusuma (Eds.) Teknologi Budi Daya Laut dan Pengembangan Sea Farming di Indonesia, Depertemen Kelautan dan Perikanan, p. $201-206$.

Suwirya, K., N.A. Giri, dan M. Marzuqi. 2003. Pengaruh n3 HUFA pada pertumbuhan benih kerapu macan, Epinephelus fuscogutatus. J. Pen. Per. Indonesia.

Tucker, J.W.Jr., W.A. Lelies, G.K. Vermeer, D.E. Robert Jr, and P.N. Woodward. 1997. The effect of experimental starter diets with different levels of soybean or menhadeoil on red drum (Sciaenops ocellalus). Aquaculture, 149: 323-339.

Takeuchi, T. and T. Watanabe. 1979. Effects of excess amount of essential fatty acid on growth of rainbow trout. Bull. Japan Soc. Sci. Fish., 46: 1,517-1,519.

Vergara, J.M., L. Ropbiana, M. Izquierdo, and M.D.L. Higuera. 1996. Protein sparing effect of lipid in the diets for fingerlings of gilthead seabream. Fish. Sci., 62(4): $624-628$.

Watanabe, T., T. Takeuchi, and C. Ogino. 1975. Effect of dietary methyl linolenate and linoleate on growth of carp. Bull. Jpn. Soc. Sci. Fish., 41(2): 263-269.

Watanabe, T., C. Kitajima, and S. Fujita. 1983. Nutritional values of live organisms used in japan for mass propogation of fish: a review. Aquaculture, 34: 115143.

Watanabe, T. 1982. Lipid nutrition in fish. Comp. Biochem. Physiol., 73: 3-15.

Webster, C.D. and R.T. Lovell. 1990. Respone of stripped bass larvae fed brine shrimp from different sources containing different fatty acids composition. Aquaculture, 90: 49-61.

Williems, C.D. and E.H. Robinson. 1988. Respone of red drum to various dietary levels of manhaden oil. Aquaculture, 70: 107-120.

Yano, Y. and M. Fujii. 1975. Studies on nutrition of red sea bream IX: Effect of $n-3$ fatty acid supplement in a corn oil diet on growth and feed efficiency. Bull. Jpn. Soc. Sci. Fish., 41: 73-77.

Yu, T.C. and R.O. Sinhuber. 1976. Growth response of rainbow trout (Salmo gairdneri) to dietary n-3 and n6 fatty acids. Aquaculture, 8: 309-317.

Yu, T.C. and R.O. Sinhuber. 1979. Effects of dietary n-3 and n-6 fatty acids on growth and feed convertion efficiency of coho salmon (Oncorhychus kisutch). Aquaculture, 16: 31-38. 